\title{
Article \\ Planning Peri-Urban Open Spaces: Methods and Tools for Interpretation and Classification
}

\author{
Enrico Gottero $^{1, * \mathbb{D}}$, Claudia Cassatella ${ }^{2}$ and Federica Larcher ${ }^{1} \mathbb{D}$ \\ 1 Department of Agricultural, Forest and Food Sciences, University of Turin, Largo Paolo Braccini 2, \\ 10095 Grugliasco, TO, Italy; federica.larcher@unito.it \\ 2 Interuniversity Department of Regional and Urban Studies and Planning (DIST), Politecnico di Torino, \\ Viale Mattioli 39, 10125 Turin, Italy; claudia.cassatella@polito.it \\ * Correspondence: enrico.gottero@polito.it
}

check for updates

Citation: Gottero, E.; Cassatella, C.; Larcher, F. Planning Peri-Urban Open Spaces: Methods and Tools for Interpretation and Classification. Land 2021, 10, 802. https://doi.org/ $10.3390 /$ land 10080802

Academic Editors: Roberto Henke and Francesco Vanni

Received: 22 June 2021

Accepted: 27 July 2021

Published: 30 July 2021

Publisher's Note: MDPI stays neutral with regard to jurisdictional claims in published maps and institutional affiliations.

Copyright: (c) 2021 by the authors. Licensee MDPI, Basel, Switzerland. This article is an open access article distributed under the terms and conditions of the Creative Commons Attribution (CC BY) license (https:/ / creativecommons.org/licenses/by/ $4.0 /)$.

\begin{abstract}
Today, planning an urban-rural interface requires redefining the planner's role and toolbox. Global challenges such as food security, climate change and population growth have become urgent issues to be addressed, especially for the implications in land use management. Urban-rural linkages, socio-economic interactions and ecological connectivity are the main issues on which the new urban agenda and sustainable development goals focus. Thus, urban and peri-urban agriculture (professional and not professional) in urban-rural interfaces has a crucial role in the maintenance and enhancement of landscape quality, urban green spaces and ecosystem services. The research presented in this article adopts a holistic approach, with a special focus on open spaces, in order to understand the complexity of peri-urban landscapes and to identify homogeneous units. It also defines map-based indices to characterize peri-urban landscape types and identify main functions to maintain and enhance. The method was applied to the peri-urban area of Turin (Italy), and maps of spatial and functional classification at the landscape unit level were generated, as well as a map of critical areas to improve. Despite some minor limitations, the method and tools proposed appear to have a range of applications in the context of global challenges and from a landscape perspective.
\end{abstract}

Keywords: peri-urbanization; landscape planning; peri-urban landscape; landscape analysis; ruralurban interface; map-based indicators; open spaces; peri-urban classification

\section{Introduction}

Since the late 1990s, peri-urban areas have evoked strong interest in several scientific and institutional contexts, especially in the field of territorial disciplines for governing the complex system of relations between the city and countryside. Peri-urbanization is a rapidly expanding phenomenon, mainly in European cities, as a consequence of settlement and infrastructural development. In the last decade, it has taken agricultural land and amplified the social and economic rift between urban and rural areas [1].

There is no universal definition of peri-urban-areas. Indeed, they are difficult to identify due to the extraordinary variety and dynamism. A peri-urban-area is a zone of contact between city and countryside characterized by material and immaterial relationships, where a system of functional, socio-economic, spatial and ecosystemic relations is recognizable between rural areas and urban areas [2,3]. Peri-urban areas are also characterized by low population density and a high degree of urbanization/fragmentation and by the presence of important open spaces (mainly agricultural) for the provision of ecosystem services-such as food provision; regulation of the water cycle; mitigation of heat islands; support for biodiversity and ecological connectivity and for the maintenance of green and blue infrastructures; outdoor recreational services near to densely populated areas and conservation of traditional landscape features. These areas include not only important agricultural lands but also woodlands, urban green areas, protected areas and urbanized areas (built-up areas and infrastructures). They are places where agriculture, especially 
professional, plays a decisive role in the conservation and enhancement of the open spaces around cities.

A current rich framework of literature references underlines the importance and centrality of peri-urban spaces in the context of urban studies and in the research field of spatial planning. This topic has been addressed from different perspectives. Some scholars have studied these areas [4-7] in terms of food and the link between the agri-food product and its context (food environment), the food supply chains and the urban and peri-urban supply system, food safety and quality, alternative and innovative production and sales practices. Other scholars have instead examined the potential and critical issues of the multifunctionality and diversification in the field of agriculture, especially in intraurban, peri-urban and fringe areas [8-13]. Other work has focused on social and not professional agriculture (urban and peri-urban gardening) [14,15], as well as urban sprawl issues $[9,16]$. In the last decade several studies on the spatial dimension of peri-urban landscapes have been conducted, mainly in terms of land conservation, land degradation and consumption, urban-rural dichotomy, identification of peri-urban boundaries [17-20], spatial relationships between the city and countryside and governance systems [21-23] as well as driving forces of the peri-urbanization [24]. Several papers have further focused on environmental benefits [25-31], ecosystem functions, nature-based solutions, possible trade-off of agroecosystems in peri-urban areas [32-34] and cultural and recreational services [35-37].

This work demonstrates a holistic approach to understanding the complexity of periurban landscapes, with a focus on the role of open spaces. The research presented in this paper aims to systematize and assess peri-urban landscape values, to identify and classify homogeneous units and types, in order to develop the framework for setting the criteria and guidelines for planning strategies at different territorial scales and in the broadest context possible. This method was applied to the peri-urban area of Turin (Italy) in the context of a number of in-depth studies for the new General Territorial Plan of the Turin Metropolitan Area. Considering its features and complexity, the application on this area could be helpful for understanding other similar peri-urban areas and to replicate the method in other European contexts.

In the second section, the authors show the case study, the method to define the knowledge framework and to classify peri-urban landscape units. In the third section, some results of the application in the Turin case study are described, both in terms of structural interpretation and spatial and functional classification. The results are interpreted in the discussion section, and the strengths and limitations are highlighted, together with possible fields and contexts of application, as well as the lessons learned. In the last section, the authors discuss some open questions and research perspectives regarding peri-urban open spaces in the field of planning and in the context of global challenges.

\section{Materials and Methods}

\subsection{The Case Study}

The Turin peri-urban area (TPA) is an area of $658 \mathrm{sq} \mathrm{km}$ in the north-west of Italy (Piedmont Region) that has nearly 1.5 million inhabitants today. The boundaries of the TPA have been defined in a previous study in the context of the new General Territorial Plan of the Turin Metropolitan Area. The TPA borders hills to the east and the pre-mountain zone and the Morenic hills to the west. The TPA extends from the plain grassland areas in the north to the cereal and horticultural crop zones in the south, and it is included in a radius of $20 \mathrm{~km}$ from the urban center of Turin (Figure 1). The TPA is characterized by a complex environmental system that includes several rivers (Po, Stura, Dora Riparia, Sangone) and a dense network of irrigation canals, as well as the protected areas of La Mandria and Stupinigi (at the north-west and south, respectively). These areas are also recognized as European Sites of Community Importance (SCIs) and Savoy Royal Residences. The TPA is characterized by lowland areas with widespread and sparse buildings (developed between 1960 and 2000), while more recently the buildings have appeared mainly in the western 
area. The main roads are located in the south and north-east areas, while existing and under construction/project railways are in the south-west. The TPA includes several brownfield areas, especially in the south-west and north-east, as well as those in densely built-up urban contexts (the core area). The TPA also contains a system of historical agricultural farms belonging to the religious order of the "Mauriziano" in the south-west area, as well as many historical farmhouses and dispersed rural settlements especially in the south and north-east. In terms of scenic values, the TPA includes some natural fulcrums, the Stupinigi and Corso Francia perspective axes and several visual fulcrums in the north-west area. It consists of a dense network of footpaths and cycle/pedestrian paths, especially in the west and south-east, as well as numerous tourist destinations, spread mainly between the south and west (Figure 2).

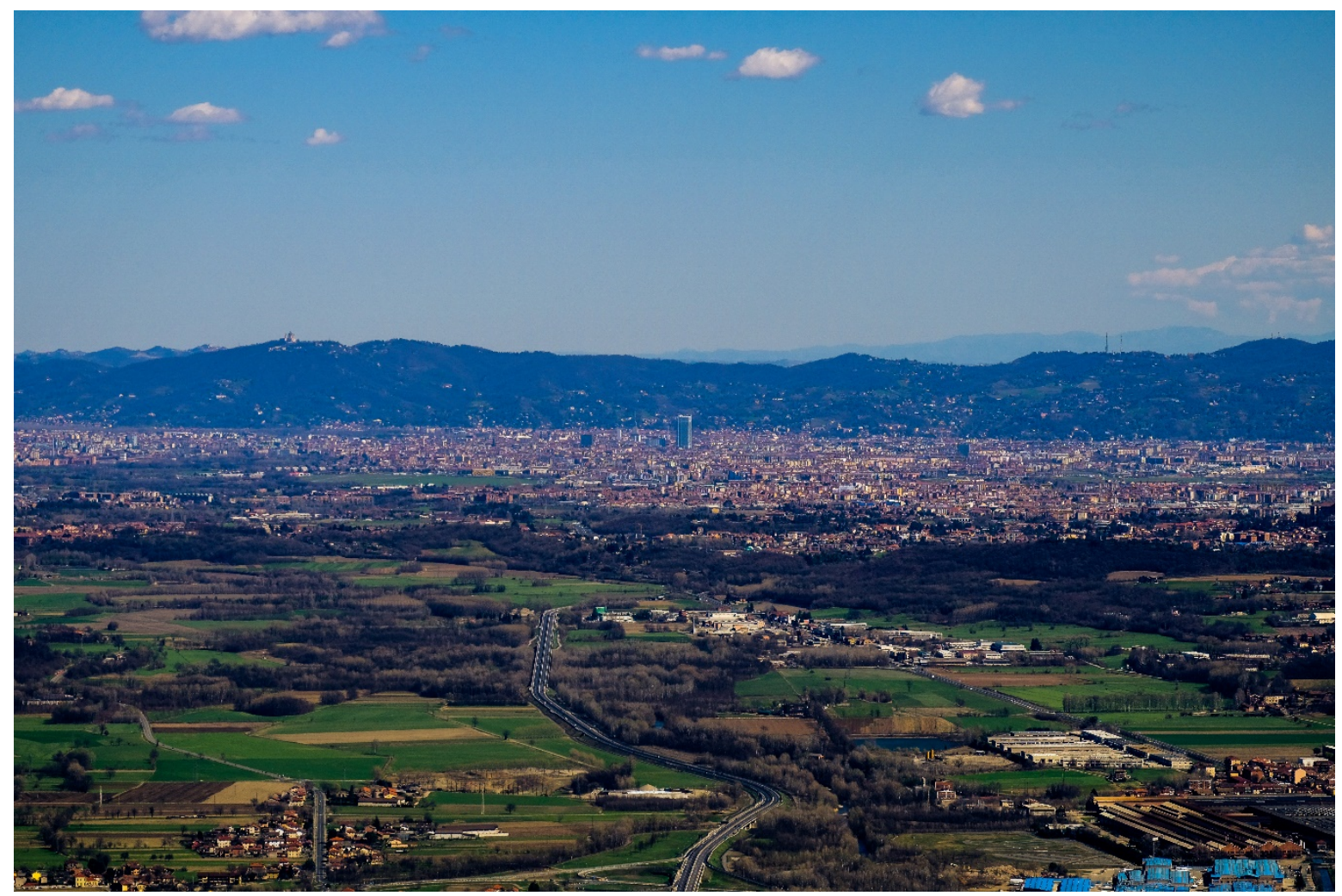

Figure 1. The TPA from panoramic points at the Sacra di San Michele (Photo: Mauro Volpiano).

\subsection{Method}

The method to analyze peri-urban areas includes two parts: the definition of the knowledge framework and the classification of peri-urban landscape units (Figure 3).

\subsubsection{Definition of the Knowledge Framework for a Peri-Urban Landscape}

Based on the main methods for the characterization and interpretation of landscape [38-40], the knowledge framework is divided into two parts. The first concerns the recognition of the peri-urban landscape value system. It contains the collection and processing of different numerical and spatial data from national, regional and local producers, as well as at different levels. It includes the systematization and spatialization of different data on landscape components and other validated values that characterize a peri-urban area (listed in Appendix A). This analysis concerns the identification of the following dimensions of peri-urban landscape character: environmental (protected areas and ecological networks, water networks, land cover and use, forests, hedge networks, areas of agronomic or landscape interest, areas vulnerable to nitrates and pesticides, organic agricultural areas); 
morphological and settlement components (settlement systems and phases, existing and planned infrastructures, abandoned and degraded areas, building areas, land use changes); areas, buildings and other elements of historical and cultural interest; scenic elements (visibility, perspective axes, panoramic points and routes); fruition components and recreational networks (soft mobility rural networks, cycle and pedestrian paths, greenways, tourist destinations) as well as socio-economic dimensions (land consumption, socio-demographic dynamics, dynamics of the agricultural production system, number of farms, oriented urban farms, urban food gardens, traditional and quality agri-food chains).

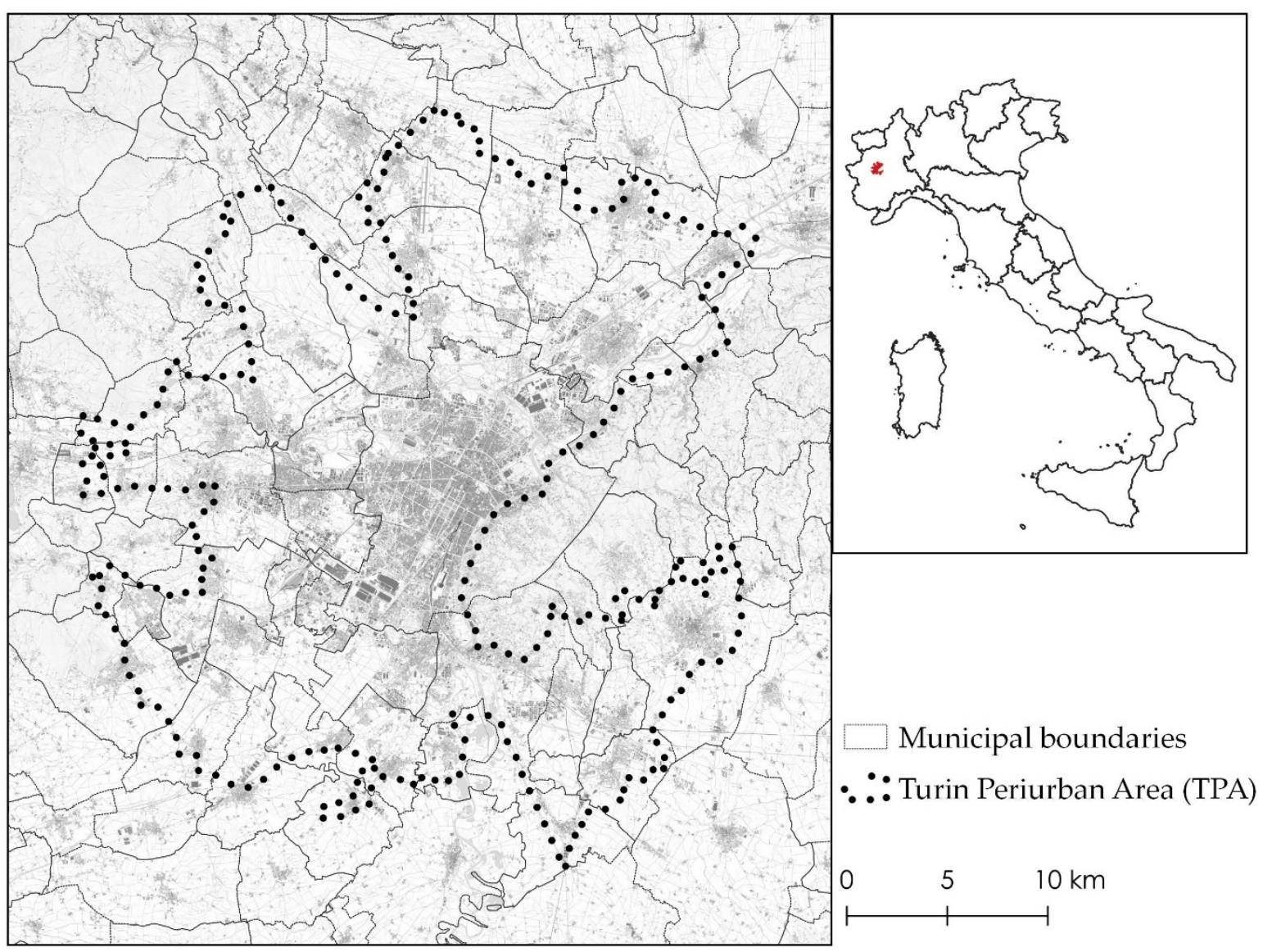

Figure 2. Map of the Turin peri-urban area (TPA).

The second step includes the peri-urban landscape structural interpretation. It consists of the identification and spatialization of the structuring, qualifying and characterizing factors, as well as the main territorial issues and dynamics. The structuring factors are stable and permanent elements that can condition the transformation processes (for example, historical road systems and railway lines, landscape structure, rivers). Instead the characterizing elements include relationships that characterize each area and distinguish it from the others, making it recognizable (typical settlements, terracing, etc.). Finally, the qualifying components represent elements or conditions that confer a particular quality or value without modifying the landscape structure (buildings of particular interest, natural elements, etc.) [39].

The structural interpretation supports the following stages and allows the identification of the units of analysis. The peri-urban landscape units were traced considering the physical structure of the peri-urban territory, such as rivers, roads and built-up areas (structuring factors), as well as types of physical barriers bordering open spaces. 


\section{Knowledge framework}

\section{Classification}

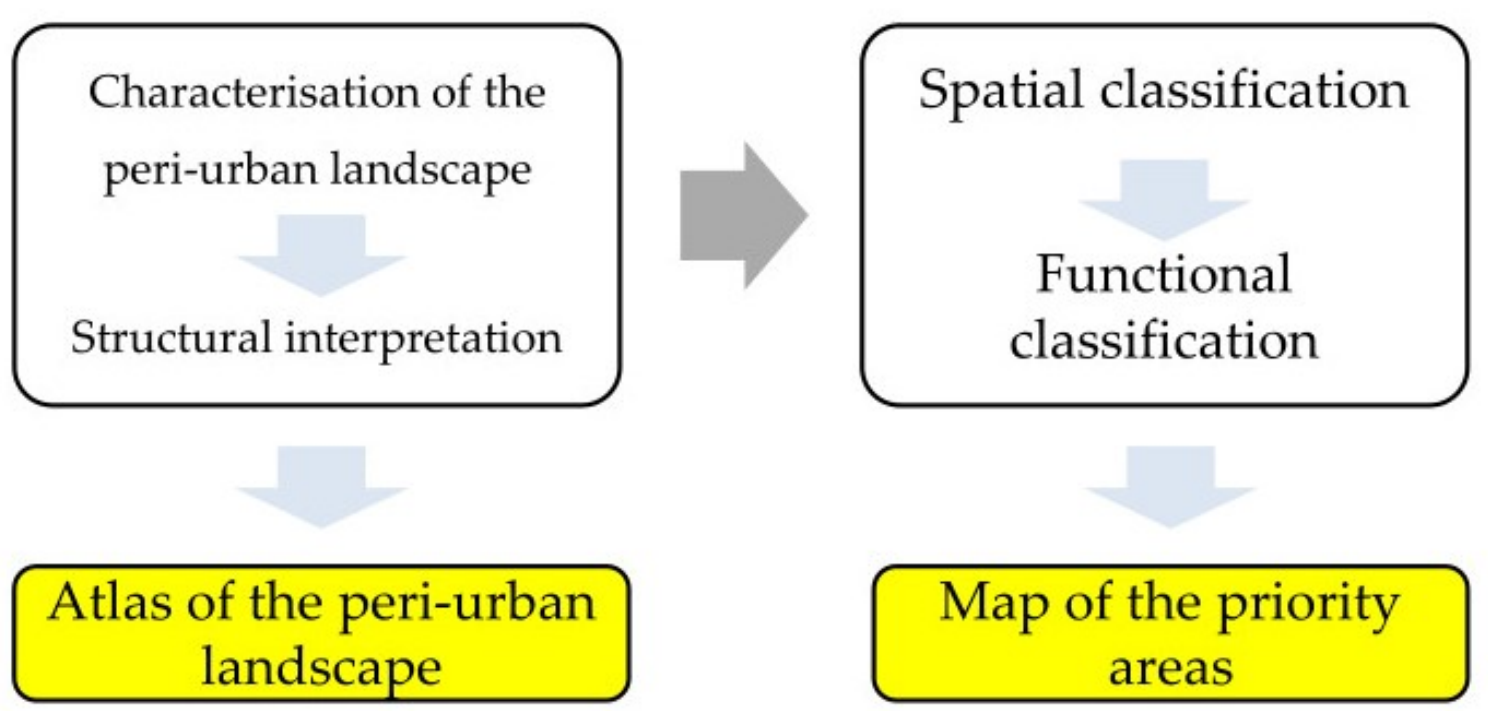

Figure 3. Flowchart.

\subsubsection{The Spatial Classification of Peri-Urban Open Spaces}

The first step of this second phase consists of the spatial and dimensional classification of peri-urban landscape units. These units were classified firstly based on the permeability and occlusion of the perimeters, assigning weights in relation to the type of physical barrier that constitutes the perimeter of the unit (see Table 1). This classification allows the identification of three typologies: open agricultural spaces (predominantly permeable areas), urban-rural connection spaces and interclosed areas (predominantly impermeable areas).

Table 1. Occlusion coefficients of perimeters.

\begin{tabular}{cc}
\hline Types of Perimeters & $p_{i}$ \\
\hline Compact buildings, highways, large railways, interclosed areas (total blockages) & 1.0 \\
Main roads and secondary railways (high blockages) & 0.5 \\
Secondary roads (medium blockages) & 0.4 \\
Minor roads (low blockages) & 0.25 \\
Urban green spaces, natural limits, (waterways, ridges, etc.) (very low blockages) & 0.1 \\
Woods, agricultural areas, rural and farm roads, secondary roads, agricultural areas, greenways (permeable) & 0.0 \\
\hline
\end{tabular}

Source: our elaboration from [41,42].

The occlusion of perimeters can be calculated through the following Equation (1):

$$
I_{o c}=\sum_{i}^{n} P_{i} \times p_{i}
$$

where:

$$
\begin{gathered}
P_{i}=\text { Perimeter length with } p_{i} \\
p_{i}=\text { Occlusion coefficients. }
\end{gathered}
$$

\subsubsection{The Functional Classification of Peri-Urban Open Spaces}

The second step of the peri-urban classification is based on the knowledge framework and starts from the updating of any other existing classifications. In the case of the TPA, "The guidelines for the Turin peri-urban landscape" (2012) and "Strategic plan of green 
spaces in the Turin metropolitan area", both from the Turin Metropolitan public authority, were helpful in the identification of landscape functions. The peri-urban landscape units were subsequently classified through weighting map-based indices (values from 0 to 1 ) defined by an expert-based analysis in order to support policymaking (Table 2). This approach was selected considering the main ecosystem functions, the multidimensionality of peri-urban landscapes, the replicability and transferability in the European context, the existence of geographic information and data-source (see dataset in Appendix A) as well as the applicability at local scale. This method identified five types of peri-urban areas and the corresponding map-based indices that can be calculated through Equation (2). In addition, the spatial data, functions and indicators were validated by the Turin Metropolitan public authority during the definition of the functional classification.

$$
\text { In }=f\left(p_{i}, I_{i}\right)=\sum_{i}^{n} p_{i} I_{i}
$$

where:

$$
p_{i}=\text { Weighting coefficient. }
$$

High agricultural productivityareas (If)

High agricultural productivity areas are areas where the productive agricultural components are relevant in terms of food supply, presence of structured farms and urbanoriented farms or valuable, traditional or organic crops.

$I_{U A A}=$ utilized agricultural area/landscape unit area;

$I_{F A}=$ Food production area/utilized agricultural area of the landscape unit;

$I_{\text {OUC }}=$ organic utilized agricultural area/utilized agricultural area of the landscape unit;

$I_{O U F}=$ number of oriented urban farms/maximum number of oriented urban farms for the landscape unit.

Food production area includes arable land, vineyards and orchards. Oriented urban farms (OUFs) refers to multifunctional farms.

Imageability areas (Ii)

Imageability areas are areas where the signs of the historical memory of the landscape (such as historical roads, canals and farmhouses, traditional crops, trees and hedge networks) are recognizable.

$I_{H S}=$ area with a high density of historical and cultural signs/landscape unit area;

$I_{H L}=$ hedge length in the landscape unit/maximum hedge length for the landscape unit;

$I_{L H I}=$ length of historic irrigation canals in the landscape unit/maximum length of historic irrigation canals for the landscape unit;

$I_{H R}=$ length of historic roads in the landscape unit/maximum length of historic roads for the landscape unit;

$I_{H P}=$ number of historic point elements in the landscape unit/maximum number of historic point elements for the landscape unit.

High natural value areas (Ihv)

High natural value areas are areas where the numbers of ecological elements (linear, point and areal) and the level of naturalness are very high.

$I_{P A}=$ protected area/landscape unit area;

$I_{H L}=$ hedge length in the landscape unit/maximum hedge length for the landscape unit;

$I_{P M}=$ permanent meadow area/utilized agricultural area for the landscape unit.

Scenic value areas (Isv)

Scenic value areas are areas visible from the main observation points and where the components of the scenic landscape are most present (visual fulcrums, panoramic points and routes).

$I_{V A}=$ visible area from sights/landscape unit area;

$I_{N P}=$ number of point elements in the landscape unit/maximum number of point elements at landscape unit; 
$I_{L P R}=$ length of panoramic routes in the landscape unit/maximum length of panoramic routes for the landscape unit.

Recreational areas (Ir)

Recreational areas are areas with good accessibility to the system of green areas, characterized by a dense and soft mobility rural network, cycle and pedestrian paths and greenways.

$I_{P G A}=$ average population that can access green areas of the landscape unit/maximum number of population that can access green areas at the landscape unit;

$I_{C R N}=$ number of cornerstones of the recreational network in the landscape unit/ maximum number of cornerstones of the recreational network for the landscape unit;

$I_{L P}=$ length of paths in the landscape unit/maximum length of paths for the landscape unit.

Table 2. Criteria for the functional classification of peri-urban open spaces.

\begin{tabular}{|c|c|c|c|}
\hline Map-Based Index & Functions & Indicator & $p_{i}$ \\
\hline High agricultural productivity areas (If) & Food provision & $\begin{array}{c}\mathrm{I}_{\mathrm{UAA}} \\
\mathrm{I}_{\mathrm{FA}} \\
I_{\text {OUC }} \\
I_{\text {OUF }}\end{array}$ & $\begin{array}{l}0.3 \\
0.5 \\
0.1 \\
0.1 \\
\end{array}$ \\
\hline Imageability areas $\left(\mathrm{I}_{\mathrm{i}}\right)$ & Historical and cultural & $\begin{array}{l}\mathrm{I}_{\mathrm{HS}} \\
\mathrm{I}_{\mathrm{HL}} \\
I_{L H I} \\
I_{H R} \\
I_{H P}\end{array}$ & $\begin{array}{l}0.5 \\
0.1 \\
0.1 \\
0.1 \\
0.2\end{array}$ \\
\hline High natural value areas $\left(\mathrm{I}_{\mathrm{hv}}\right)$ & Ecological & $\begin{array}{l}\mathrm{I}_{\mathrm{PA}} \\
\mathrm{I}_{\mathrm{HL}} \\
I_{P M}\end{array}$ & $\begin{array}{l}0.5 \\
0.25 \\
0.25\end{array}$ \\
\hline Scenic value areas $\left(\mathrm{I}_{\mathrm{sv}}\right)$ & Scenic & $\begin{array}{l}\mathrm{I}_{\mathrm{VA}} \\
\mathrm{I}_{\mathrm{NP}} \\
\mathrm{I}_{L P R}\end{array}$ & $\begin{array}{c}0.5 \\
0.25 \\
0.25\end{array}$ \\
\hline Recreational areas $\left(\mathrm{I}_{\mathrm{r}}\right)$ & Fruitive and recreational & $\begin{array}{c}\mathrm{I}_{\mathrm{PGA}} \\
\mathrm{I}_{\mathrm{CRN}} \\
\mathrm{I}_{L P}\end{array}$ & $\begin{array}{l}0.25 \\
0.25 \\
0.5\end{array}$ \\
\hline
\end{tabular}

\section{Results}

\subsection{The Characterization and Structural Interpretation of the Turin Peri-Urban Landscape}

The outputs of this reconnaissance and interpretative phase were collected in a landscape atlas that includes 25 maps considering environmental, morphological-settlement, historicalcultural, scenic and recreational as well as socio-economic dimensions (Appendix A). This spatial information, mainly vectors at different cartographic scales, was integrated and combined at the 1:150.000 scale within thematic maps, as a part of the new General Territorial Plan of the Turin Metropolitan Area. In addition, the atlas consists of a structural interpretation map and a weaknesses map for the identification of the peri-urban landscape units.

The structural interpretation of the TPA has highlighted its most significant structural factors, which include the extensive hydrographic network (the rivers and the irrigation system) and the historical settlement system characterized by physical elements such as the historical road and the railway network. In addition, the Turin peri-urban landscape includes characteristic elements that distinguish it from other landscapes such as perspective axes and some rural systems along rivers and several traditional landscapes in the north and south-west of the core area. The main qualifying components are instead the woods and the oak-hornbeam groves in the protected areas of Stupinigi and La Mandria, the irrigation infrastructures as well as hedges, rows and permanent meadows, which mainly 
spread to the north. The farmhouses for agricultural use and of historical-cultural interest are instead present in significant numbers in the north-west and south-west.

The structural interpretation phase also highlighted the most significant critical nodes, areas and networks. The TPA is characterized by several point elements with a strong environmental impact, such as quarries, landfills and built-up areas, especially in the northeast and south-west. The infrastructures with a strong environmental and visual impact, in addition to the highway network, concern the arterial systems along the roads to the south-west, south-east and north. To the south-west, the planned railway infrastructures could further compromise an area already covered by numerous linear elements with a strong impact and high urban sprawl. The issue of land take by urbanization also involves the western area, the pre-hill zone, as well as the north of the core area. According to Munafò [43], land consumption has produced a reduction of the flow of agricultural production especially in the south-east farmland area. In this area and in the west of the core zone, there are also the main professionally oriented urban farms. The agro-forestry areas in the north, west and in the south-east quadrant are also strongly threatened by the expansion of urban areas, in part due to their low agronomic interest. These areas, in particular in the north and south-east quadrant, are also the most vulnerable to nitrates and pesticides. The areas that require more attention from the hydrogeological point of view are near to the rivers in the south-east, west quadrant and in the northern area. The rural system along the rivers (especially Sangone, Dora Riparia and Stura) is also characterized by several invasion woods and non-native species.

The structuring factors, the urbanized areas and densely built-up areas identified in the previous phase make it possible to outline the borders of the open spaces and the peri-urban landscape units. In the, TPA 80 units were drawn, of which two are entirely urban or densely urbanized, i.e., core areas 78-79. These two core areas were excluded from the analysis (Figure 4).

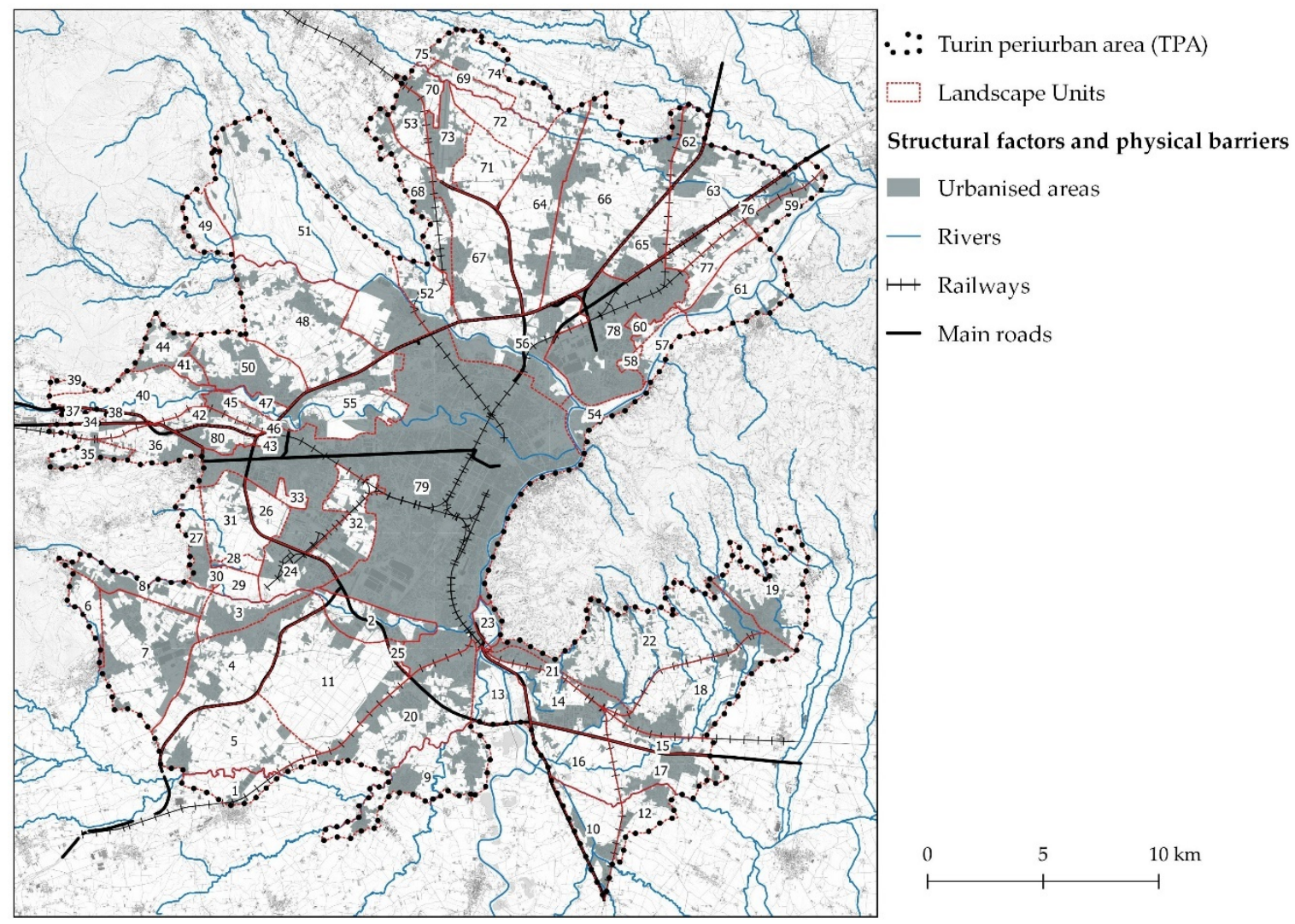

Figure 4. Map of the peri-urban landscape units. 


\subsection{The Spatial and Functional Classification of the Turin Peri-Urban Landscape}

In the Turin peri-urban area, the built-up areas that show welding tendencies are those in the north and south-east as well as in the west. These are open spaces to be safeguarded in order to ensure the supply of cultural and biological services and consolidate the urban green system, also from a recreational perspective. The most significant agricultural open spaces are those in the north-west. In the south, the units are mostly permeable and ensure the urban-rural connection, especially between units 11 and 20, near to the Stupinigi Natural Park. This is also the case in the south-east, between units 22 and 18. The most extensive units are included in protected areas of La Mandria and Stupinigi, as well as in the agricultural areas between units 22 and 18. The smallest units, especially to the west, are often interclosed areas. In general, the spatial classification highlighted that the results could change over time, in particular in the urban-rural connection spaces. In the near future, due to urban sprawl, some of these areas near the urban core could become interclosed areas and lose their ecosystem functions (Figure 5).

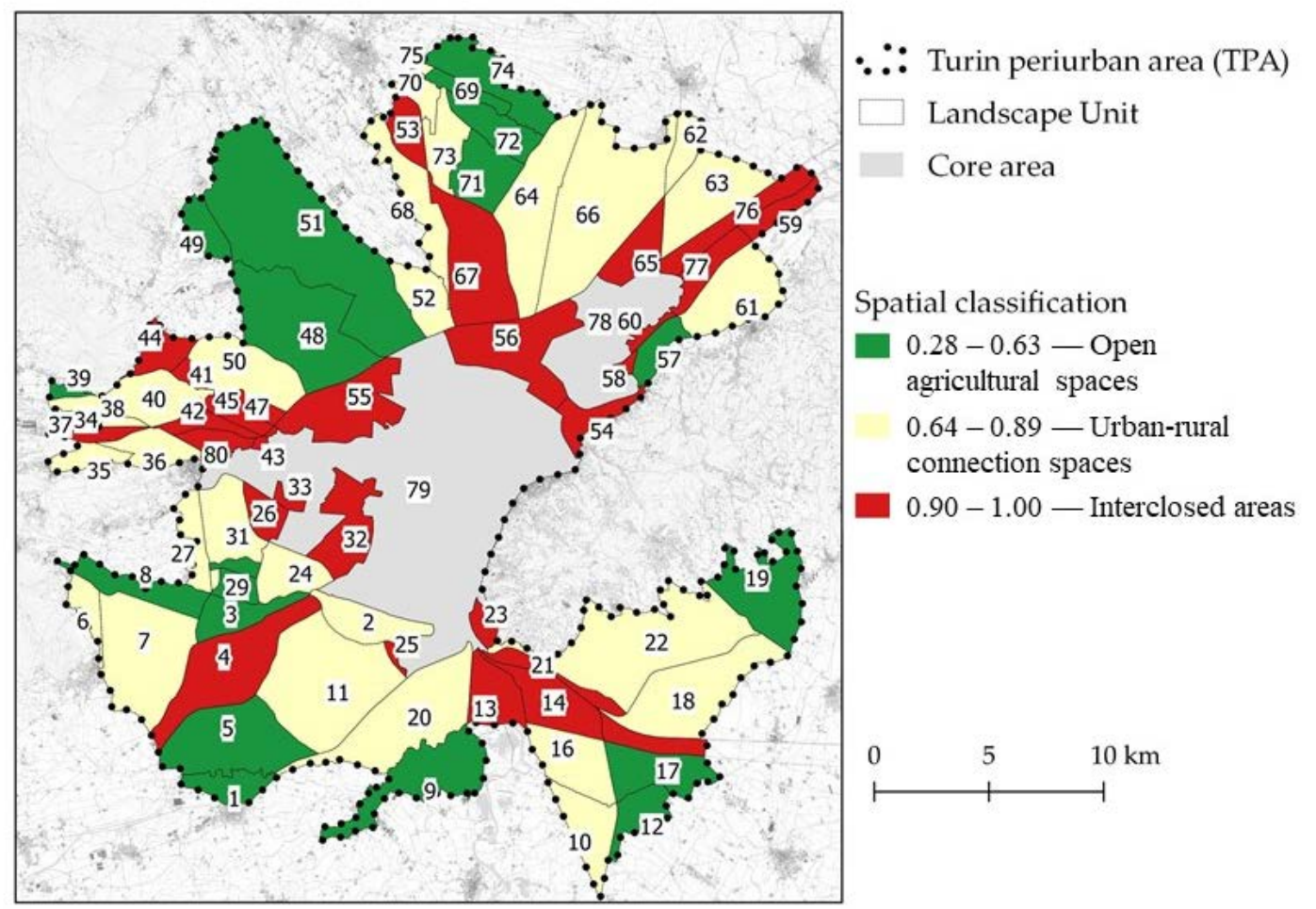

Figure 5. Map of the spatial classification of peri-urban landscape units.

The functional classification shows the functional level (low, medium, high) of each unit. As can be seen in Figure 6, the functions are not mutually excluded, and they often overlap. The areas of productive and food value are mainly on the southern side of the Turin peri-urban area, in particular in the pre-hilly area, in the plains, as well as near to the Stupinigi Natural Park. In these areas organic practices are concentrated, and most of the farms are oriented to the urban market. The production is less significant in the north-west quadrant, where grassland and woodland areas prevail. Instead the western border of the urban area is probably limited by urban sprawl and infrastructures (Figure 6a). 


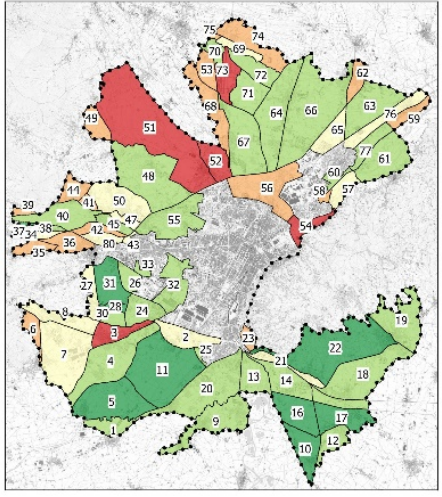

(a)

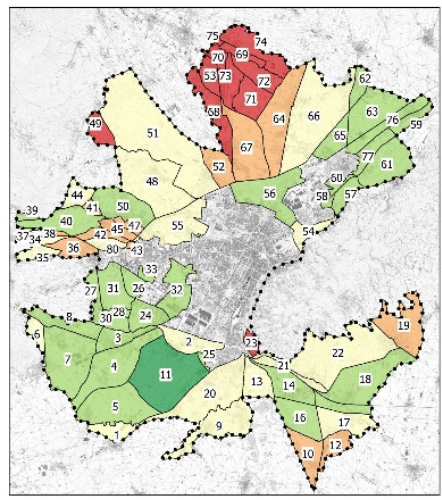

(d)

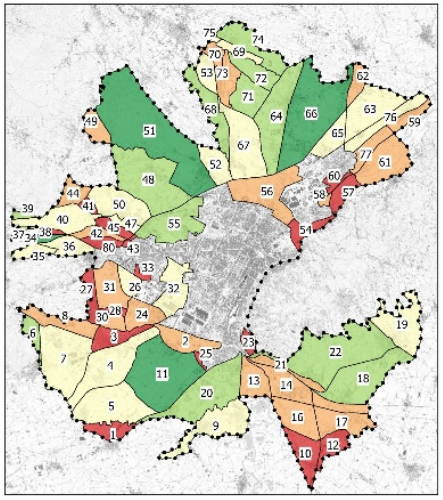

(b)

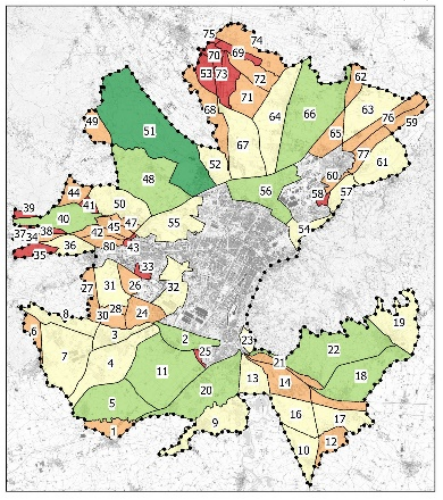

(e)

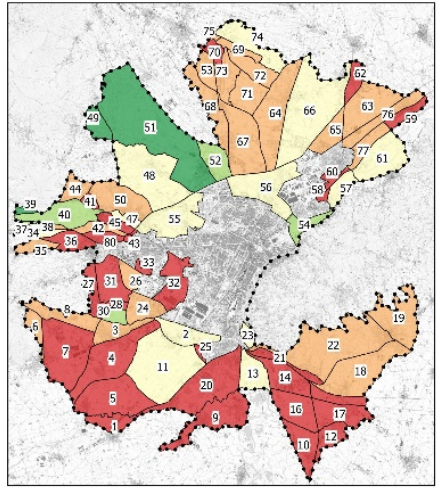

(c)

$$
\therefore: \text { Turin periurban area (TPA) }
$$

$\square$ Landscape Unit

Functional classification

In low

medium

high

Figure 6. Functional classification according to the following functions: (a) food provision; (b) historical and cultural; (c) ecological; (d) scenic; (e) recreational.

From the point of view of historical and cultural recognizability, in terms of the permanence of components of the traditional rural landscape such as hedges, trees, canals, historic roads, farmhouses, the TPA is characterized by the presence of four units of fundamental importance: the Savoy residences of Venaria and Stupinigi, and the plains between units 48 and 51, and units 66 and 64 . These are areas in which there are not only numerous specific components but also areas where the matrix of the historical agricultural landscape is still recognizable. The contribution of the south-east, south-west and a large part of the north-eastern areas is less significant (Figure 6b).

In addition to the multipurpose areas of the Stupinigi Natural Park and the La Mandria Natural Park, the other units in the north-west quadrant, in the Dora Riparia safeguard area and part of the Sangone river corridor are very important in terms of high natural value. In these areas, the extensive protected zone in relation to the territorial one as well as the presence of habitats and components of the ecological network such as permanent meadows and hedges represent the main elements. Furthermore, the contribution of the south-east quadrant and part of the southern slope of the Turin suburbs seems less relevant, probably due to the presence of intensive agriculture (Figure 6c).

The areas of particular perceptual-visual value concern mainly the north-east and south-west quadrant, as well as some units to the south-east and corresponding to the Dora river safeguard area. The southern part of the TPA and the north-east between units 65 and 76, are areas of high visual sensitivity, while between units 11 and 7 the presence of natural fulcrums, punctual components and scenic routes has prevailed. The north-west quadrant is less significant from the point of view of the presence of the components of the scenic landscape, especially near the north-west municipalities (Figure 6d).

The Stupinigi Natural Park and the La Mandria Natural Park are also of greater importance than the other units of the TPA in terms of recreation value. These areas are characterized by a good accessibility to the green spaces, the presence of numerous tourist 
destinations and a dense network of recreational infrastructures. The north side and the west side are instead areas where it is necessary to strengthen the infrastructural equipment for recreational activities and leisure (Figure 6e).

The functional classification produced maps of distribution of the map-based index (Figure 6) and identified the main functions to be maintained and strengthened in the TPA. It also produced a map that includes priority areas, in relation to the number of functions with critical indicator values (Figure 7). This approach allows decision-makers to identify where and how interventions should be focused and how many or what functions should be enhanced and/or maintained.

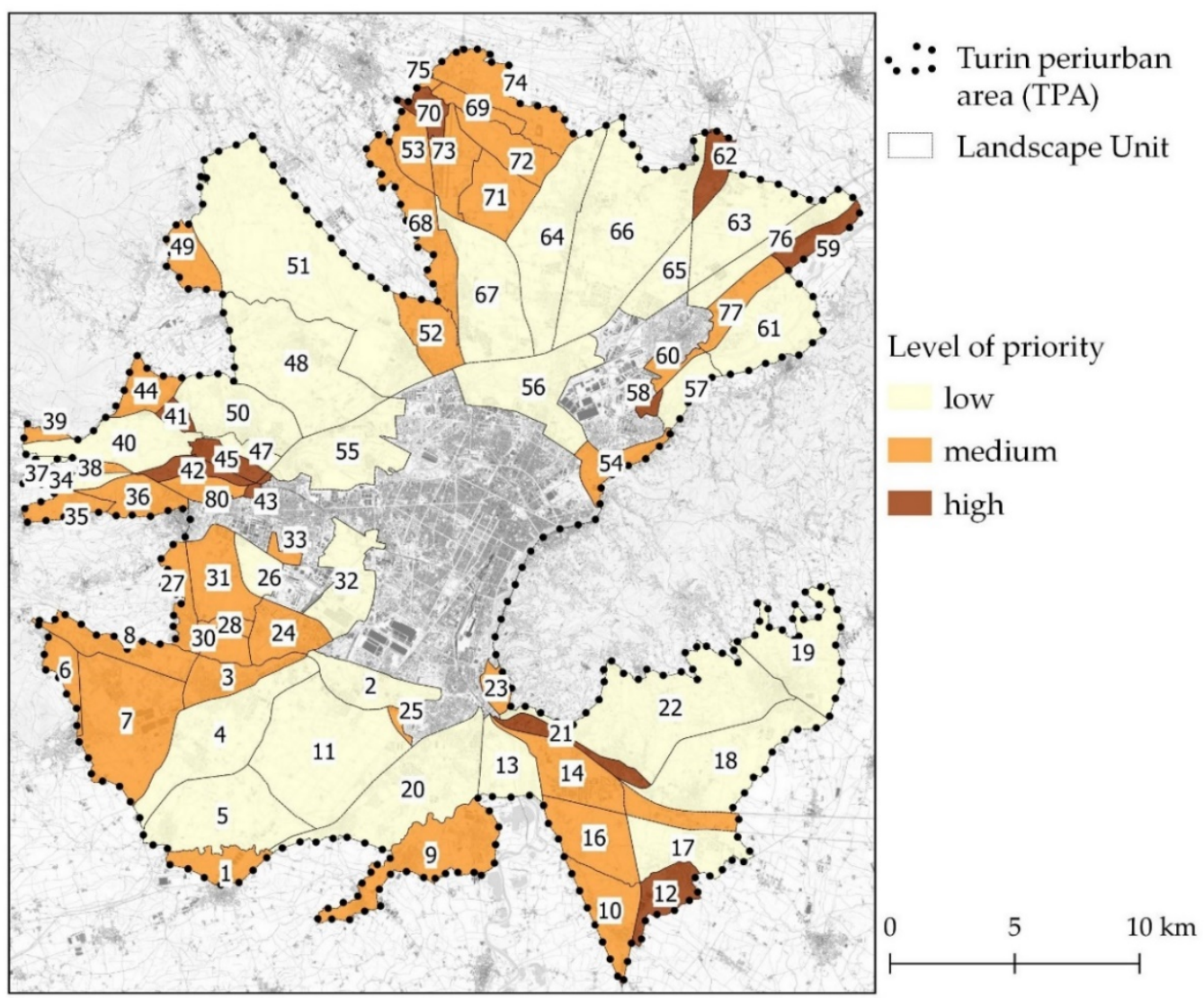

Figure 7. Map of the priority areas.

\section{Discussion}

The findings of the research carried out in the Turin case study have raised some recurring issues in fringe areas and in the field of planning of peri-urban open spaces, both on the theoretical and applicative level, as well as strengths and weaknesses. These include:

- Method limits: The lack, reliability and updating of some spatial data, in particular regarding recreational areas and infrastructures, land use, scenic landscape components and professional farmers, could be a relevant issue for the development of a knowledge framework and structural interpretation, especially in a peri-urban landscape. The scale of territorial analysis is another issue to be considered. The analysis was conducted at the metropolitan level and at landscape units, merging several data at different original cartographic scales. Combining information at different scales could be a critical point. For the TPA, many data were more detailed than the required scales or than the scale of the new General Territorial Plan of the Turin Metropolitan Area. Regarding spatial classification, the identification of the landscape units does not take into account altimetry and geography (for example hilly or flat areas). In 
addition, the results of this classification should be updated and verified periodically, according to land use changes. The functional classification and, in particular, the choice of functional categories and map-based indicators, as well as the assignment of weighting coefficients, could be critical points to be tackled. In our opinion, the five typologies are exhaustive for the TPA, but this may not be the case for other areas. To overcome these issues, it would be helpful to select and validate these tools through focus groups and the involvement of policymakers and other stakeholders.

- Transferability to other contexts: The absence or lack of spatial data could be a relevant issue for the application in metropolitan contexts. However, this problem can be solved with in-depth analyses, also at a local scale. Other limitations could regard the representativeness of the selected functional categories and indicators, as well as the difficult delimitation of a peri-urban border (it is often not defined).

- Possible field of application and perspectives: In view of urban agenda fields, the European Green Deal and the 2030 Agenda for Sustainable Development, some tangible fields of application of the method and tools developed in this research are strategic planning at different scales, guidelines for open spaces, green belt strategies and plans for urban green areas, parks and protected areas. This research can contribute to strengthening food security and sustainable agriculture (SDG 2), as well as to maintaining and enhancing green infrastructures, promoting nature-based solutions (NBSs) and sustainable settlement planning (SDG 11). For example, the results of this research could be helpful to identify prevalent functions (to be maintained and enhanced), landscape dimensions to be strengthened, critical or priority areas as well as rules and new forms for open space management. This method could be useful to implement supra-local strategies in order to identify existing and potential vulnerabilities and opportunities, as well as to define integrated meta-planning tools and address recurring issues in peri-urban areas. In addition, structural funds, such as the Common Agricultural Policy (CAP) and rural development programs, could also be testing fields where it would be useful to identify and assess targeted strategies for urban and peri-urban agriculture.

\section{Conclusions}

This research highlights two issues on peri-urban areas that are likely to increase the urban-rural gap: the current urban-centered approach and the technical gap in the framework to address global challenges. Firstly, a new balance between city and countryside is needed, in accordance with the new long-term vision for European rural areas [44]. This vision has recently highlighted the importance of connections with peri-urban and urban areas. It requires the transition from urban to agro-urban vision, adopting an approach no longer focused on urban development but on agricultural planning, new types of public policies and innovative forms of governance in order to support agriculture in peri-urban areas. According to Hedblom et al. [28], it is important to change the perception of periurban areas. They are not only areas located between city and countryside with a specific features (population density, urbanization, geographical distance) but are also recognizable landscapes for the provision of different ecosystem functions. Such an approach would also require an effort on an educational and training level in order to define specific transdisciplinary skills and new professional roles. The second issue concerns the planning and project tools to meet new global and European challenges: not only the global growing food demand and the increase in population but also the SDG targets, climate neutrality, the Biodiversity Strategy for 2030 as well as "farm to fork" targets. Urban-rural fringes and agricultural open spaces in peri-urban areas are places that planners usually do not handle, but they could be useful to meeting global demands and EU targets, for example, increasing green spaces, decreasing land consumption, increasing organic farming and biodiversity-rich landscape features, reducing the use of pesticides, increasing protected areas, planting trees and restoring rivers. In the coming years, planners will have an 
obligation to reflect on possible integrated and multiscale policy and planning tools to manage and design peri-urban open spaces.

Author Contributions: Conceptualization: all authors; methodology: all authors; validation: C.C. and F.L.; formal analysis: E.G.; investigation: E.G.; data curation: E.G.; writing-original draft preparation: all authors; writing —review and editing: all authors; visualization: E.G.; supervision: C.C. and F.L.; project administration: F.L.; funding acquisition: F.L. All authors have read and agreed to the published version of the manuscript.

Funding: This research was funded by Città Metropolitana di Torino.

Data Availability Statement: Some publicly available datasets were analyzed in this study (see: Appendix A). The new data were created in this study are not publicly available due to restrictions. They are available from the corresponding author with the permission of Turin Metropolitan Area Authority.

Acknowledgments: The authors would like to thank Simonetta Alberico, Paola Vayr and Gabriele Bovo (Turin Metropolitan Area Authority) for the valuable contribution and discussion.

Conflicts of Interest: The authors declare no conflict of interest. The funders had no role in the design of the study; in the collection, analyses, and interpretation of data; in the writing of the manuscript or in the decision to publish the results. 


\section{Appendix A}

Table A1. Main spatial outputs and datasets for the definition of the knowledge framework.

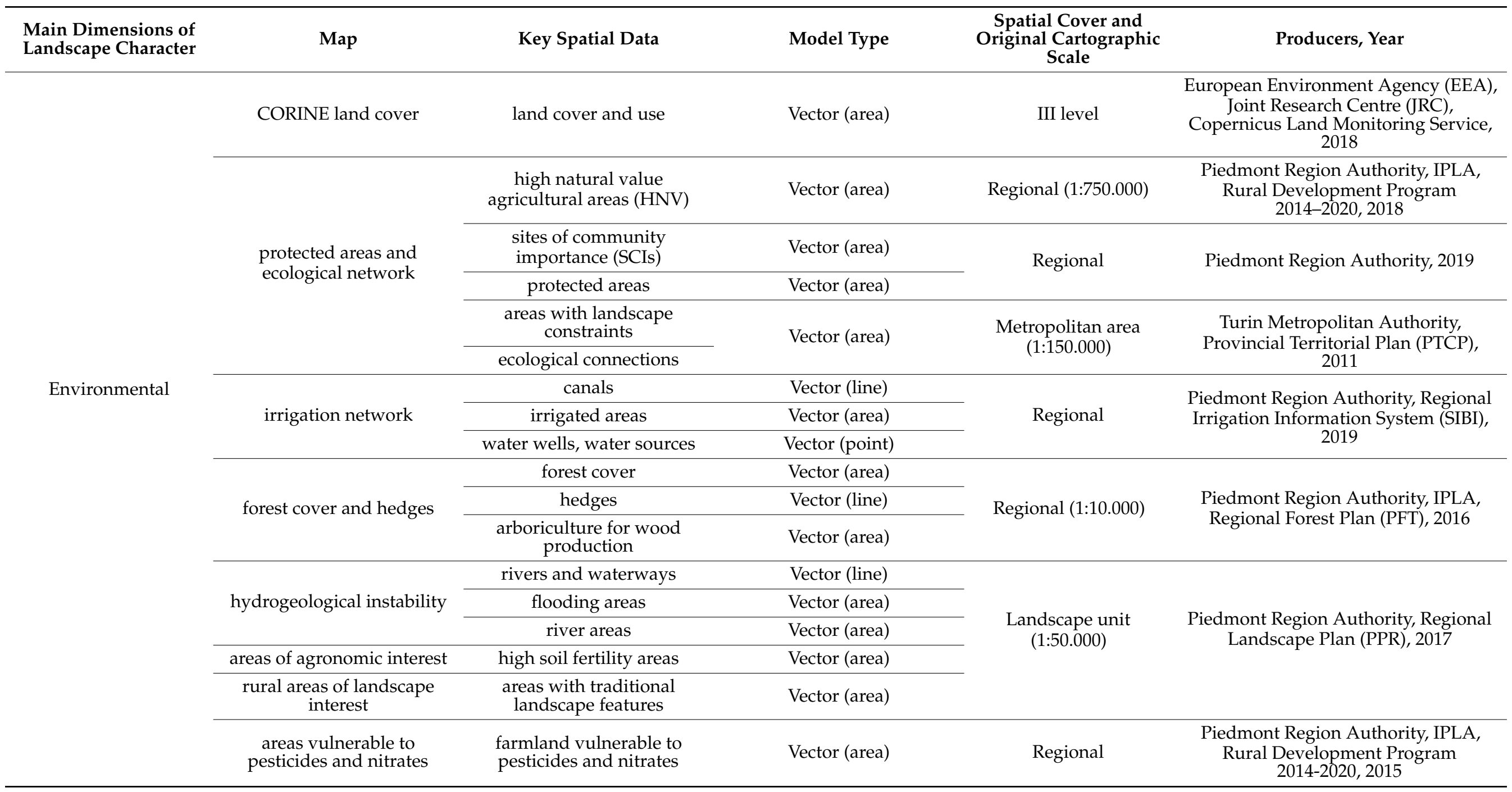


Table A1. Cont.

\begin{tabular}{|c|c|c|c|c|c|}
\hline $\begin{array}{l}\text { Main Dimensions of } \\
\text { Landscape Character }\end{array}$ & Map & Key Spatial Data & Model Type & $\begin{array}{c}\text { Spatial Cover and } \\
\text { Original Cartographic } \\
\text { Scale }\end{array}$ & Producers, Year \\
\hline Environmental & organic farming areas & $\begin{array}{l}\text { farmland with organic } \\
\text { farming production }\end{array}$ & Vector (area) & Regional & $\begin{array}{c}\text { Piedmont Region Authority, Regional } \\
\text { Farm Register (AAU), } 2018\end{array}$ \\
\hline \multirow{5}{*}{$\begin{array}{l}\text { Morphological and } \\
\text { settlement }\end{array}$} & Urban Atlas & urban land cover and use & Vector (area) & $\begin{array}{l}\text { Functional Urbana } \\
\text { Area (FUA) }\end{array}$ & $\begin{array}{c}\text { European Environment Agency (EEA), } \\
\text { Joint Research Centre (JRC), } \\
\text { Copernicus Land Monitoring Service, } \\
2018\end{array}$ \\
\hline & $\begin{array}{l}\text { existing and planned } \\
\text { infrastructures }\end{array}$ & $\begin{array}{l}\text { highways, main roads, } \\
\text { railway }\end{array}$ & Vector (line) & \multirow{3}{*}{$\begin{array}{l}\text { Metropolitan area } \\
\quad(1: 150.000)\end{array}$} & \multirow{3}{*}{$\begin{array}{c}\text { Turin Metropolitan Authority, } \\
\text { Provincial Territorial Plan (PTCP), } \\
2011\end{array}$} \\
\hline & settlement phases & $\begin{array}{l}\text { construction phases of built } \\
\text { up areas }\end{array}$ & Vector (area) & & \\
\hline & critical areas & $\begin{array}{l}\text { degraded or disused areas, } \\
\text { building areas }\end{array}$ & & & \\
\hline & land use change & land cover and use changes & Vector (area) & III level & $\begin{array}{c}\text { European Environment Agency (EEA), } \\
\text { Joint Research Centre (JRC), } \\
\text { Copernicus Land Monitoring Service, } \\
2012 \text { and } 2018\end{array}$ \\
\hline \multirow{4}{*}{ Historical and cultural } & \multirow[t]{2}{*}{ cultural heritage } & $\begin{array}{l}\text { areas with landscape } \\
\text { constraints }\end{array}$ & Vector (area) & $\begin{array}{l}\text { Landscape unit } \\
\quad(1: 50.000)\end{array}$ & $\begin{array}{l}\text { Piedmont Region Authority, Regional } \\
\text { Landscape Plan (PPR), } 2017\end{array}$ \\
\hline & & $\begin{array}{l}\text { elements of cultural } \\
\text { heritage, royal residences }\end{array}$ & Vector (point) & $\begin{array}{l}\text { Metropolitan area } \\
\quad(1: 150.000)\end{array}$ & $\begin{array}{c}\text { Turin Metropolitan Authority, } \\
\text { Provincial Territorial Plan (PTCP), } \\
2011\end{array}$ \\
\hline & \multirow{2}{*}{ cultural-historical system } & $\begin{array}{l}\text { buildings of historical } \\
\text { interest, historical signs }\end{array}$ & Vector (point) & \multirow{4}{*}{$\begin{array}{l}\text { Landscape unit } \\
\qquad(1: 50.000)\end{array}$} & \multirow{4}{*}{$\begin{array}{c}\text { Piedmont Region Authority, Regional } \\
\text { Landscape Plan (PPR), } 2017\end{array}$} \\
\hline & & historical canals and roads & Vector (line) & & \\
\hline \multirow{2}{*}{ Scenic and recreational } & \multirow{2}{*}{ scenic components } & $\begin{array}{l}\text { visual fulcrums, panoramic } \\
\text { points }\end{array}$ & Vector (point) & & \\
\hline & & panoramic routes, skylines & Vector (line) & & \\
\hline
\end{tabular}


Table A1. Cont.

\begin{tabular}{|c|c|c|c|c|c|}
\hline $\begin{array}{l}\text { Main Dimensions of } \\
\text { Landscape Character }\end{array}$ & Map & Key Spatial Data & Model Type & $\begin{array}{c}\text { Spatial Cover and } \\
\text { Original Cartographic } \\
\text { Scale }\end{array}$ & Producers, Year \\
\hline \multirow{6}{*}{ Scenic and recreational } & visible areas & $\begin{array}{l}\text { visible areas from } \\
\text { panoramic points }\end{array}$ & Vector (area) & Regional & Piedmont Region Authority, 2017 \\
\hline & \multirow{5}{*}{ recreational system } & cycle and pedestrian paths & Vector (line) & $\begin{array}{l}\text { Metropolitan Area } \\
\quad(1: 150.000)\end{array}$ & $\begin{array}{c}\text { Turin Metropolitan Authority, } \\
\text { Provincial Territorial Plan (PTCP), } \\
2011 \\
\end{array}$ \\
\hline & & $\begin{array}{l}\text { tourist destinations, } \\
\text { archeological sites, } \\
\text { eco-museums }\end{array}$ & Vector (point) & \multirow[t]{2}{*}{$\begin{array}{l}\text { Landscape unit } \\
\quad(1: 50.000)\end{array}$} & \multirow[t]{2}{*}{$\begin{array}{c}\text { Piedmont Region Authority, Regional } \\
\text { Landscape Plan (PPR), } 2017\end{array}$} \\
\hline & & Greenways & Vector (line) & & \\
\hline & & protected areas & Vector (area) & Regional & Piedmont Region Authority, 2019 \\
\hline & & $\begin{array}{l}\text { urban green spaces (Urban } \\
\text { Atlas) }\end{array}$ & Vector (area) & $\begin{array}{l}\text { Functional Urbana } \\
\text { Area (FUA) }\end{array}$ & $\begin{array}{c}\text { European Environment Agency (EEA), } \\
\text { Joint Research Centre (JRC), } \\
\text { Copernicus Land Monitoring Service, } \\
2018\end{array}$ \\
\hline \multirow{10}{*}{ Socio-economic } & \multirow{2}{*}{$\begin{array}{c}\text { land consumption } \\
\text { (distribution at municipal } \\
\text { level)) }\end{array}$} & urban sprawl & numerical & \multirow{2}{*}{ Municipal } & \multirow{2}{*}{$\begin{array}{l}\text { Italian Institute for Environmental } \\
\text { Protection and Research (ISPRA), } 2019\end{array}$} \\
\hline & & $\begin{array}{l}\text { rate of change in land } \\
\text { consumption }\end{array}$ & & & \\
\hline & \multirow{4}{*}{$\begin{array}{l}\text { socio-demographic } \\
\text { dynamics (distribution at } \\
\text { municipal level)) }\end{array}$} & average income & numerical & \multirow{4}{*}{ Municipal } & \multirow{4}{*}{$\begin{array}{l}\text { Italian National Institute of Statistics } \\
\text { (ISTAT), } 2018 \text { and } 2015\end{array}$} \\
\hline & & number of inhabitants & & & \\
\hline & & natural balance & & & \\
\hline & & migratory balance & & & \\
\hline & \multirow{4}{*}{$\begin{array}{l}\text { agricultural production } \\
\text { system }\end{array}$} & $\begin{array}{l}\text { ratio of utilized agricultural } \\
\text { area (UAA) to total area }\end{array}$ & numerical & \multirow{4}{*}{ Municipal } & \multirow{4}{*}{$\begin{array}{l}\text { Piedmont Region Authority, Regional } \\
\text { Farm Register (AAU), } 2018\end{array}$} \\
\hline & & $\begin{array}{l}\text { change in utilized } \\
\text { agricultural area (UAA) }\end{array}$ & & & \\
\hline & & number of farms & & & \\
\hline & & change in number of farms & & & \\
\hline
\end{tabular}


Table A1. Cont.

\begin{tabular}{|c|c|c|c|c|c|}
\hline $\begin{array}{l}\text { Main Dimensions of } \\
\text { Landscape Character }\end{array}$ & Map & Key Spatial Data & Model Type & $\begin{array}{c}\text { Spatial Cover and } \\
\text { Original Cartographic } \\
\text { Scale }\end{array}$ & Producers, Year \\
\hline \multirow{6}{*}{ Socio-economic } & \multirow{2}{*}{ metropolitan agriculture } & oriented urban farms & Vector (point) & \multirow{2}{*}{$\begin{array}{l}\text { Turin metropolitan } \\
\text { area }\end{array}$} & \multirow{2}{*}[41]{} \\
\hline & & urban food gardens & & & \\
\hline & \multirow{4}{*}{$\begin{array}{l}\text { traditional and quality food } \\
\text { chain }\end{array}$} & $\begin{array}{l}\text { Farms with traditional } \\
\text { agri-food products }\end{array}$ & Vector (point) & Regional & $\begin{array}{l}\text { Piedmont Region Authority, Regional } \\
\text { database of traditional agri-food } \\
\text { products, } 2016\end{array}$ \\
\hline & & farmers' markets & Vector (point) & \multirow{2}{*}{ Regional } & \multirow{2}{*}{$\begin{array}{l}\text { Coldiretti farmers association, } \\
\text { Regional database, } 2016\end{array}$} \\
\hline & & direct sale on farm & & & \\
\hline & & $\begin{array}{l}\text { restaurants and sales of } \\
\text { local food products }\end{array}$ & Vector (point) & $\begin{array}{l}\text { Turin metropolitan } \\
\text { area }\end{array}$ & $\begin{array}{l}\text { Turin Metropolitan Authority, } \\
\text { Metropolitan register of local } \\
\text { agri-food products, } 2012\end{array}$ \\
\hline
\end{tabular}




\section{References}

1. European Environment Agency (EEA). Urban Sprawl in Europe; Joint EEA-FOEN Report; Publications Office of the European Union: Luxembourg, 2016.

2. European Economic and Social Committee (EESC). Opinion of the European Economic and Social Committee on 'Agriculture in Peri-Urban Areas', (2005/C 74/12). 2004. Available online: https://eur-lex.europa.eu/legal-content/EN/TXT/PDF/?uri= CELEX:52004IE1209\&from=IT (accessed on 14 July 2021).

3. Piorr, A.; Ravetz, J.; Tosics, I. (Eds.) Peri-Urbanisation in Europe. Towards a European Policy to Sustain Urban-Rural Futures; Synthesis Report; University of Copenhagen/Academic Books Life Sciences: Copenhagen, Denmark, 2011.

4. Hatab, A.A.; Cavinato, M.E.R.; Lagerkvist, C.J. Urbanization, livestock systems and food security in developing countries: A systematic review of the literature. Food Secur. 2019, 11, 279-299. [CrossRef]

5. Taylor, E.; Butt, A.; Amati, M. Making the Blood Broil: Conflicts over Imagined Rurality in Peri-Urban Australia. Plan. Pract. Res. 2017, 32, 85-102. [CrossRef]

6. Olsson, E.G.A.; Kerselaers, E.; Kristensen, L.S.; Primdahl, J.; Rogge, E.; Wästfelt, A. Peri-urban food production and its relation to urban resilience. Sustainability 2016, 8, 1340. [CrossRef]

7. Magoni, M.; Colucci, A. Protection of Peri-Urban Open Spaces and Food-System Strategies. The Case of Parco delle Risaie in Milan. Plan. Pract. Res. 2017, 32, 40-54. [CrossRef]

8. Bertoni, D.; Cavicchioli, D. Farm succession, occupational choice and farm adaptation at the rural-urban interface: The case of Italian horticultural farms. Land Use Policy 2016, 57, 739-748. [CrossRef]

9. Duvernoy, I.; Zambon, I.; Sateriano, A.; Salvati, L. Pictures from the other side of the fringe: Urban growth and peri-urban agriculture in a post-industrial city (Toulouse, France). J. Rural Stud. 2018, 57, 25-35. [CrossRef]

10. Gullino, P.; Battisti, L.; Larcher, F. Linking multifunctionality and sustainability for valuing peri-urban farming: A case study in the Turin Metropolitan Area (Italy). Sustainability 2018, 10, 1625. [CrossRef]

11. Kristensen, S.B.P.; Præstholm, S.; Busck, A.G.; Winther, L.; Fertner, C.; Vesterager, J.P.; Vejre, H. On-farm Business Structure Diversification in Greater Copenhagen-Farmers in an urban landscape or entrepreneurs in a rural landscape? Land Use Policy 2019, 88, 104093. [CrossRef]

12. Rolf, W.; Pauleit, S.; Wiggering, H. A stakeholder approach, door opener for farmland and multifunctionality in urban green infrastructure. Urban For. Urban Green. 2019, 40, 73-83. [CrossRef]

13. Spataru, A.; Faggian, R.; Docking, A. Principles of multifunctional agriculture for supporting agriculture in metropolitan peri-urban areas: The case of Greater Melbourne, Australia. J. Rural Stud. 2020, 74, 34-44. [CrossRef]

14. Delgado, C. Contrasting practices and perceptions of urban agriculture in Portugal. Int. J. Urban Sustain. Dev. 2018, 10, 170-185. [CrossRef]

15. Pace Ricci, J.M.; Conrad, E. Exploring the feasibility of setting up community allotments on abandoned agricultural land: A place, people, policy approach. Land Use Policy 2018, 79, 102-115. [CrossRef]

16. Akimowicz, M.; Cummings, H.; Landman, K. Green lights in the Greenbelt? A qualitative analysis of farm investment decisionmaking in peri-urban Southern Ontario. Land Use Policy 2016, 55, 24-36. [CrossRef]

17. Amirinejad, G.; Donehue, P.; Baker, D. Ambiguity at the peri-urban interface in Australia. Land Use Policy 2018, 78, 472-480. [CrossRef]

18. Goncalves, J.; Castilho Gomes, M.; Ezequiel, S.; Moreira, F.; Loupa-Ramos, I. Differentiating peri-urban areas: A transdisciplinary approach towards a typology. Land Use Policy 2017, 63, 331-341. [CrossRef]

19. Mortoja, M.G.; Yigitcanlar, T.; Mayere, S. What is the most suitable methodological approach to demarcate peri-urban areas? A systematic review of the literature. Land Use Policy 2020, 95, 104601. [CrossRef]

20. Nilsson, K. Peri-Urban Land Use Relationships_PLUREL Project Strategies and Sustainability Assessment Tools for Urban-Rural Linkages; Publishable final activity report; University of Copenhagen: Copenhagen, Denmark, 2011.

21. AA.VV. RURBANCE. For a Balanced Development of the Relations between Rural and Urban Areas. Final Report. Available online: http: / / www.alpine-space.org/2007-2013/projects/projects/detail/RURBANCE/show /index.html (accessed on 27 January 2016).

22. Pedroli, B.; Pinto Correia, T.; Primdahl, J. Challenges for a shared European countryside of uncertain future. Towards a modern community-based landscape perspective. Landsc. Res. 2016, 41, 450-460. [CrossRef]

23. Perrin, C.; Nougarèdes, B.; Sini, L.; Branduini, P.; Salvati, L. Governance changes in peri-urban farmland protection following decentralisation: A comparison between Montpellier (France) and Rome (Italy). Land Use Policy 2018, 70, 535-546. [CrossRef]

24. Dadashpoor, H.; Ahani, S. Explaining objective forces, driving forces, and causal mechanisms affecting the formation and expansion of the peri-urban areas: A critical realism approach. Land Use Policy 2021, 102, 105232. [CrossRef]

25. Capotorti, G.; De Lazzari, V.; Ortí, M.A. Local scale prioritisation of green infrastructure for enhancing biodiversity in Peri-Urban agroecosystems: A multi-step process applied in the Metropolitan City of Rome (Italy). Sustainability 2019, 11, 3322. [CrossRef]

26. De Montis, A.; Caschili, S.; Mulas, M.; Modica, G.; Ganciu, A.; Bardi, A.; Ledda, A.; Dessena, L.; Laudari, L.; Fichera, C.R. Urban-rural ecological networks for landscape planning. Land Use Policy 2016, 50, 312-327. [CrossRef]

27. De Montis, A.; Ganciu, A.; Cabras, M.; Bardi, A.; Mulas, M. Comparative ecological network analysis: An application to Italy. Land Use Policy 2019, 81, 714-724. [CrossRef] 
28. Hedblom, M.; Andersson, E.; Borgström, S. Flexible land-use and undefined governance: From threats to potentials in peri-urban landscape planning. Land Use Policy 2017, 63, 523-527. [CrossRef]

29. Marando, F.; Salvatori, E.; Sebastiani, A.; Fusaro, L.; Manes, F. Regulating Ecosystem Services and Green Infrastructure: Assessment of Urban Heat Island effect mitigation in the municipality of Rome, Italy. Ecol. Model. 2019, 392, 92-102. [CrossRef]

30. Pérez-Campaña, R.; Valenzuela-Montes, L.M. Nodes of a peri-urban agricultural landscape at local level: An interpretation of their contribution to the eco-structure. J. Environ. Plan. Manag. 2018, 61, 406-429. [CrossRef]

31. Roussel, F.; Schulp, C.J.E.; Verburg, P.H.; van Teeffelen, A.J.A. Testing the applicability of ecosystem services mapping methods for peri-urban contexts: A case study for Paris. Ecol. Indic. 2017, 83, 504-514. [CrossRef]

32. Llausàs, A.; Buxton, M.; Beilin, R. Spatial planning and changing landscapes: A failure of policy in peri-urban Victoria, Australia. J. Environ. Plan. Manag. 2016, 59, 1304-1322. [CrossRef]

33. Pérez-Neira, D.; Grollmus-Venegas, A. Life-cycle energy assessment and carbon footprint of peri-urban horticulture. A comparative case study of local food systems in Spain. Landsc. Urban Plan. 2018, 172, 60-68. [CrossRef]

34. Spyra, M.; La Rosa, D.; Zasada, I.; Sylla, M.; Shkaruba, A. Governance of ecosystem services trade-offs in peri-urban landscapes. Land Use Policy 2020, 95, 104617. [CrossRef]

35. Kalfas, D.G.; Zagkas, D.T.; Dragozi, E.I.; Zagkas, T.D. Estimating value of the ecosystem services in the urban and peri-urban green of a town Florina-Greece, using the CV. Int. J. Sustain. Dev. World Ecol. 2020, 27, 310-321. [CrossRef]

36. Komossa, F.; van der Zanden, E.H.; Verburg, P.H. Characterizing outdoor recreation user groups: A typology of peri-urban recreationists in the Kromme Rijn area, the Netherlands. Land Use Policy 2019, 80, 246-258. [CrossRef]

37. Žlender, V.; Gemin, S. Testing urban dwellers' sense of place towards leisure and recreational peri-urban green open spaces in two European cities. Cities 2020, 98, 102579. [CrossRef]

38. Cassatella, C.; Peano, A. (Eds.) Landscape Indicators. Assessing and Monitoring Landscape Quality; Springer: Dordrecht, The Netherlands, 2011.

39. Cassatella, C. L'interpretazione strutturale del paesaggio e il piano come risorsa conoscitiva [The interpretation of landscape structure and the plan as a knowledge resource]. Atti E Rass. Tec. Della Soc. Degli Ing. E Degli Archit. Torino 2018, 3, $63-67$.

40. Tudor, C. An Approach to Landscape Character Assessment; Natural England: York, UK, 2014.

41. Gottero, E.; Cassatella, C. Spatial Tools to Renew the Planning Paradigm through Metropolitan Agriculture. The Case Study of Turin (Italy). In Agrourbanism: Tools for Governance and Planning of Agrarian Landscape; Gottero, E., Ed.; GeoJournal Library; Springer: Cham, Switzerland, 2019; Volume 124, pp. 241-258.

42. Gottero, E. Identifying vulnerable farmland: An index to capture high urbanisation risk areas. Ecol. Indic. 2019, 98, 61-67. [CrossRef]

43. Munafò, M. (Ed.) Consumo di Suolo, Dinamiche Territoriali e Servizi Ecosistemici. Edizione 2019; Report SNPA 08/2019; SNPA: Rome, Italy, 2019.

44. European Commission (EC). A Long-Term Vision for the EU's Rural Areas-Towards Stronger, Connected, Resilient and Prosperous Rural Areas by 2040; COM(2021) 345 Final; European Commission (EC): Brussels, Belgium, 2021. 